Volume 1 No (1) 2019

\title{
Pertanggung jawaban Hukum Terhadap Anak Sebagai Pelaku Tindak Pidana Narkotika Di Wilayah Hukum Pengadilan Negeri Padangsidimpuan
}

\author{
Fajar Padly ${ }^{1}$ \\ ${ }^{1}$ Fakultas Hukum Universitas Muhammadiyah Tapanuli Selatan, Sumatera Utara
}

\begin{abstract}
ABSTRAK
Berdasarkan seluruh uraian yang telah penulis jelaskan di atas, maka dengan demikian sesuai dengan judul penelitian yang diangkat dalam penelitian ini adalah Pertanggungjawaban Hukum Terhadap Anak Dibawah Umur Sebagai Pelaku Tindak Pidana Narkotika Di Wilayah Hukum Pengadilan Negeri Padangsidimpuan (Studi Kasus Nomor, 05/Pid.Sus.A/2012/PN.Psp) dan seterusnya di dalam abstrak ini akan diuraikan tentang perumusan masalah, tujuan penelitian dan manfaat penelitian serta kesimpulan, dimana dengan mengamati perkembangan saat sekarang tentang tindak pidana penyalahgunaan narkotika bukan saja yang dilakukan oleh orang dewasa akan tetapi anak dibawah umur pun telah melakukan tindak pidana tersebut, maka perlu untuk dilakukan penelitian sedangkan lokasi penelitian adalah pada Pengadilan Negeri Padangsidimpuan, dan juga putusan sebagaimana tersebut di atas. Sedangkan tujuan penelitian meliputi untuk mengetahui pertanggungjawaban hokum terhadap anak dibawah umur sebagai pelaku tindak pidana narkotika di Wilayah Hukum Pengadilan Negeri Padangsidimpuan dan untuk mengetahui proses pemidanaan terhadap anak dibawah umur yang melakukan tindak pidana narkotika dalam praktek persidangan di Pengadilan Negeri Padangsidimpuan. Sedangkan teknik atau alat yang penulis gunakan dalam mengumpulkan data baik dilapangan maupun dalam melakukan wawancara dengan responden yang ditemui penulis serta data yang diambil dari dokumen yang berkaitan dengan permasalahan yang dirumuskan dalam penelitian ini yaitu Interview (Wawancara) dan Studi Dokumentasi selanjutnya akan dianalisan dengan cara Induksi dan Deduksi. Kesimpulannya adalah bahwa pertanggungjawaban hukum terhadap anak dibawah umur sebagai pelaku tindak pidana narkotika di Wilayah Hukum Pengadilan Negeri Padangsidimpuan sebagaimana yang terdapat dalam Pasal 24 Undang-undang Nomor 3 tahun 1997 tentang Pengadilan Anak bahwa tindakan yang dapat dijatuhkan kepada anak nakal ialah mengembalikan kepada orang tua, wali atau orang tua asuh, dengan menyerahkan kepada Negara untuk mengikuti pendidikan, pembinaan dan latihan kerja atau menyerahkan kepada Departemen Sosial atau organisasi Sosial Kemasyarakatan yang bergerak dibidang pendidikan, pembinaan dan latihan kerja dan bahwa proses pemidanaan terhadap anak dibawah umur yang melakukan tindak pidana penyalahgunaan narkotika dalam praktek di Pengadilan Negeri Padangsidimpuan pada dasarnya belum sesuai dengan Undang-undang 3 tahun 1997 karena seperti kasus dalam penelitian ini dimana terdakwa telah dijatuhi hukuman selama 10 (sepuluh) bulan penjara yang berarti Hakim hanya berpedoman kepada Undang-undang Nomor 35 tahun 2009 tentang Narkotika sebagaimana yang terdapat di dalam Pasal 111.
\end{abstract}

Kata Kuci : Hukum Anak, Tindak Pidana , Narkotika 


\section{PENDAHULUAN}

Masalah keadilan dan hak asasi manusia dalam kaitannya dengan penegakan hukum pidana memang bukan merupakan pekerjaan yang sederhana untuk direalisasikan. Banyak peristiwa dalam kehidupan masyarakat menunjukkan bahwa kedua hal tersebut kurang memperoleh perhatian yang serius dari pemerintah padahal sangat jelas dalam Pancasila, sebagai falsafah hidup bangsa Indonesia, masalah perikemanusiaan dan perikeadilan mendapat tempat yang sangat penting sebagai perwujudan dari Sila Kemanusiaan yang adil dan beradab serta sila Keadilan sosial bagi seluruh rakyat Indonesia.

Setiap Negara dimanapun di dunia ini wajib memberikan perhatian serta perlindungan yang cukup terhadap hak-hak anak, yang antara lain berupa hak-hak sipil, ekonomi, sosial dan budaya. Namun sepertinya kedudukan dan hak-hak anak jika dilihat dari prespektif yuridis belum mendapatkan perhatian serius baik oleh pemerintah, penegak hukum maupun masyarakat pada umumnya dan masih jauh dari apa yang sebenarnya harus diberikan kepada mereka. Kondisi inipun dipersulit oleh lemahnya penerapan hukum mengenai hak-hak anak yang dilakukan oleh aparat penegak hukum itu sendiri.

Dengan demikian apabila kita lihat dari segi pembangunan Nasional bertujuan untuk mewujudkan suatu masyarakat adil dan makmur yang merata material dan spiritual berdasarkan Pancasila dan UUD 1945 yang mengatakan :

Dalam wadah Negara Kesatuan Republik Indonesia yang merdeka, berdaulat dan bersatu dalam suasana perikehidupan bangsa yang aman, tenteram, tertib, dan dinamis dalam lingkungan pergaulan dunia yang merdeka, bersahabat, tertib, dan damai.1 Masyarakat adalah pelaku utama pembangunan dan pemerintah berkewajiban untuk mengarahkan, membimbing serta menciptakan suasana yang menunjang. Kegiatan masyarakat dan kegiatan pemerintah saling melengkapi dalam kesatuan langkah menuju tercapainya tujuan pembangunan tersebut (Dirjen Dikti Depdikbud, 1993).

Pembangunan Nasional tidak bisa lepas dari kehidupan menusia sebagai motor utama penggeraknya. Sumber daya manusia menjadi hal yang utama dalam pembangunan karena pembangunan tidak akan berjalan tanpa adanya manusia yang berkualitas. Oleh karena itu pembangunan sumber daya manusia menjadi prioritas utama yang harus digarap, karena dengan meningkatnya kualitas sumber daya manusia Indonesia menjadikan modal yang sangat penting untuk berkompetisi dalam era globalisasi saat ini. 
Penyalahgunaan obat sebagai salah satu gajala sosial dalam masyarakat Indonesia, terutama di kota-kota besar baru mulai tampak dan menjadi sebutan orang yang makin senter di manamana, sebab penyalahgunaan narkotika dan obat-obatan berbahaya lainnya oleh anak yang dalam hal ini termasuk pelajar, tidak dapat digolongkan sebagai kenakalan yang wajar. Akibat dari penyalahgunaan narkotika dan psikotropika pada anak di hari ini akan terasa akibatnya pada hari esok bagi mereka sebagai generasi penerus, maka apabila rusaknya generasi penerus berarti rapuhnya ketahanan nasional suatu bangsa.

Sebagaimana yang dikemukakan oleh Pramuka Saka Bhayangkara. 1997, yaitu : "Penyalahgunaan obat di kota-kota besar di Indonesia ternyata mempunyai corak yang lain yang belakangan ini menyerang anak-anak atau remaja usia muda. Di mana hal tersebut merupaka suatu hal yang sangat merisaukan, mengingat mereka adalah generasi yang menjadi harapan kita untuk meneruskan kelangsungan hidup bangsa secara hormat”. Ancaman bahaya penyalahgunaan narkotika dan zat adiktif lainnya adalah merupakan ancaman nasional yang perlu ditanggulangi sedini mungkin karena merupakan ancaman terhadap peradaban manusia yang pada akhirnya akan membahayakan stabilitas nasional bahkan mengancam pertahanan dan keamanan negara. Ancaman penyalahgunaan obat-obatan terlarang tersebut dapat menjadi 'kerikil tajam’ bagi kelancaran pembangunan, khususnya pembangunan sumber daya manusia, sehingga perlu ditanggulangi oleh pemerintah maupun masyarakat.

Secara merata berdasarkan pantauan Penulis melalui berbagai media, kasus penyalahgunaan narkotika yang dilakukan oleh anak seolah-olah secara sporadis telah menyentuh hampir seluruh daerah di Indonesia, baik itu kota besar, kota kecil, kabupaten, maupun desa-desa. Di Makassar pun demikian, kasus penyalahgunaan narkotika yang korbannya adalah anak semakin banyak terjadi. Dalam hal ini pemerintah telah menaruh perhatian yang sangat besar dan serius untuk menanggulangi penyalahgunakan narkotika, dan bahan-bahan adiktif lainnya, khususnya di kalangan pelajar atau remaja. Dari kalangan tertentu seperti BNN tidak bosan mengadakan seminar, symposium, lokakarya, dan sebagainya, untuk mendapatkan masukan guna menunjang usaha dan upaya pemerintah ini. Peranan masyarakat, keluarga, sekolah, dan juga lingkungan sekitar sangat penting guna menunjang dan mencegah bahaya penyalahgunaan obat-obatan tersebut, terutama narkotika yang menjadi pokok bahasan dalam penelitian ini. 
Tetapi keadaan ini sudah berlalu karena dikeluarkannya Undang-undang yang mengatur masalah narkotika yaitu Undang-Undang Nomor 35 Tahun 2009 tentang Narkotika yang telah diundangkan pada tanggal 12 Oktober 2009 sekaligus dinyatakan mulai berlaku pada tanggal undang-undang tersebut diundangkan. Undang-undang tersebut di dalamnya mengatur segala kegiatan yang berhubungan dengan masalah narkotika yang berada di bawah pengawasan Internasional. Undang-undang ini dapat dijadikan dasar hukum bagi pemerintah, khususnya penyidik kepolisian untuk menindak segala kegiatan yang ada hubungannya dengan penyalahgunaan narkotika sehingga tidak ada lagi keraguan bagi polisi untuk mencari dasar hukum yang jelas guna menindak mereka yang nyata-nyata menyimpan, menggunakan dan mengedarkan 'barang haram’ ini. Berdasarkan uraian di atas, maka penulis tertarik untuk mengadakan penelitian dengan mengangkat hal tersebut sebagai bahan penyusunan penulisan hukum yang diberi judul : "Pertanggungjawaban Hukum Terhadap Anak Dibawah Umur Sebagai Pelaku Tindak Pidana Narkotika Di Wilayah Hukum Pengadilan Negeri Padangsidimpuan “

\section{METODE PENELITIAN}

Sesuai dengan topik dan permasalahan yang dirumuskan dalam penelitian ini maka penulis akan melakukan suatu penelitian atau suatu karya ilmiah seharusnya peneliti harus menentukan dimana lokasi penelitian agar supaya memudahkan bagi penelitian dalam melakukan ataupun dalam mengumpulkan data yang ada kaitannya dengan permasalahan yang diangkat dalam penelitian Sesuai dengan penjelasan penulis tersebut di atas maka lokasi penelitian adalah Kantor Pengadilan Negeri Padangsidimpuan.

Selanjutnya penulis menguraikan bahwasanya suatu penelitian itu harus dilakukan, sebab di dalam penelitian akan sesuai dengan apa yang kita harapkan. Sejalan dengan penjelasan penulis tersebut di atas maka pendekatan penelitian yang dilakukan adalah dengan melakukan pembahasan terhadap putusan Kasus Nomor : 05/Pid.Sus.A/2012/PN.Psp dengan metode penelitian seperti dibawah ini:

1. Penelitian Kepustakaan (Library Research) yaitu dengan mengumpulkan data penelitian dengan cara mempelajari buku serta literatur lainnya yang ada hubungannya dengan masalah yang akan diteliti 
2. Penelitian Lapangan (Field Research) yaitu dengan melakukan pengumpulan data langsung terjun kelapangan untuk mengadakan wawancara dengan Hakim Pengadilan Negri Padangsidimpuan

\section{Jenis Penelitian Yang Digunakan}

Selanjutnya adapun jenis penelitian yang penulis gunakan dalam penulisan penelitian ini adalah Penelitian Kualitatif yang menggunakan sumber-sumber data skunder dan berupa peraturan Perundang-undangan, serta Putusan Pengadilan Negeri Padangsidimpuan

\section{Populasi Dan Sampel}

Sesuai dengan lokasi penelitian yang penulis sebutkan di atas selanjutnya akan dirumuskan populasi dalam penelitian ini akan tetapi sebelum penulis mengemukakan populasinya terlebih dahulu dikemukakan pengertian populasi menurut H. Hadari Nawawi yaitu : "Keseluruhan obyek penelitian yang dapat terdiri dari manusia, benda-benda, hewan, tumbuh-tumbuhan, gejala-gejala nilai test, peristiwa-peristiwa sebagai sumber daya dimiliki karakteristik tertentu di dalam suatu penelitian”,(H. Hadari Nawawi,1990).

Selanjutnya sesuai dengan penjelasan tersebut di atas maka populasi yang diambil dalam penulisan penelitian ini adalah ; para Hakim yang berada di Pengadilan Negeri Padangsidimpuan dan advokat yang berada di Kota Padangsidimpuan juga berupa putusan yang telah berkekuatan hukum tetap seperti putusan Kasus Nomor : 05/Pid.Sus.A/2012/PN.Psp

Selanjutnya penulis akan mengambil sampel terhadap penelitian ini akan mengambil sampel sebagai berikut yaitu : seorang Hakim yang berada di Pengadilan Negeri Padangsidimpuan dan juga putusan yang berkekuatan hukum tetap seperti putusan Kasus Nomor : 05/Pid.Sus.A/2012/PN.Psp

Sementara sumber data yang penulis lakukan sesuai dengan permasalahan yang telah dirumuskan adalah :

1. Data Primer yaitu data yang dihasilkan dari pendapat para responden dengan melalui wawancara

2. Data Skunder yaitu suatu data yang diambil dari literatur yang ada di perpustakaan dan Putusan Pengadilan Negeri Padangsidimpuan 


\section{Teknik Pengumpulan Data}

Selanjutnya guna untuk mengumpulkan data penelitian akan mempergunakan cara seperti berikut di bawah ini :

1. Wawancara (Interview)

Yaitu dengan melakukan wawancara langsung dengan responden yang telah ditentukan sebelumnya seperti aparat Hakim, Jaksa dan Advokat

2. Studi Dokumentasi

Yaitu dengan mengumpulkan data dari Putusan Pengadilan Negeri Padangsidimpuan yang telah berkekuatan hukum tetap yaitu seperti putusan Kasus Nomor : 05/Pid.Sus.A/2012/PN.Psp

\section{Analisa Data}

Penganlisaan terhadap penelitian ini adalah dengan mengolaha data-data yang telah diuraikan di dalam penelitian sesuai dengan objek penelitian dengan penggabungkan beberapa pengertian serta dengan melakukan pemahaman terhadap hasil penelitian dengan memakai :

1. Induksi yaitu dengan mengolah data penelitian dari hal-hal yang brsifat khusus untuk mengambil suatu kesimpulan pada hal-hal yang bersifat umum

2. Deduksi yaitu dengan mengolah data penelitian dari hal-hal yang bersifat umum untuk mengambil suatu kesimpulan pada hal-hal yang bersifat khusus

\section{PEMBAHASAN}

\section{Pertanggungjawaban Hukum Terhadap Anak Yang Melakukan Tindak Pidana Narkotika}

Kejahatan dibidang narkotika tidak seluruhnya dilakukan oleh orang dewasa akan tetapi ada kalanya kejahatan ini dilakukan pula bersama-sama dengan anak dibawah umur ataupun dapat dikatakan belum genap berusia 18 tahun, dimana anak-anak yang belum dewasa cenderung mudah dipengaruhi untuk melakukan perbuatan yang berhubungan dengan narkotika karena jiwanya belum stabil akibat perkembangan fisik dan psikis. Oleh karena itu perbuatan memanfaatkan anak dibawah umur untuk melakukan kegiatan kejahatan tindak pidana penyalahgunaan narkotika merupakan tindak pidana yang diatur dalam Undang- 
undang Narkotika Nomor 35 tahun 2009, dimana ketentuan hukumnya adalah siterdakwa dikenai dengan hukuman yang bermacam-macam diantaranya ada hukuman penjara selamalamanya 20 (dua puluh) tahun dan denda 1.000.000.000,- (satu miliyar rupiah).

Ketentuan sebagaimana yang terdapat dalam Undang-undang Nomor 35 tahun 2009 tentang narkotika tersebut hanya dikenakan terhadap orang yang memanfaatkan anak yang belum dewasa saja, sedangkan anak yang bersangkutan tetap dapat dapat dipidana berdasarkan Undang-undang Narkotika sesuai dengan perbuatannya, namun karena anak dibawah umur maka berlakulah ketentuan Undang-undang Pengadilan Anak Nomor 11 tahun 2012 ehingga berkasnya harus dipisah. Sebagaimana yang dikemukakan oleh Hakim Pengadilan Negeri Padangsidimpuan mengatakan bahwa di dalam Undang-undang Nomor 35 tahun 2009 tidak ada yang mengatur hukuman terhadap anak yang terlibat dalam narkotika, apabila terjadi kasus yang melibatkan anak dalam penyalahgunaan narkotika, maka anak tersebut merupakan anak nakal dan ketentuan hukum yang dipergunakan adalah Undang-undang Pengadilan Anak yaitu Nomor 11 tahun 2012, dimana Undang-undang tersebut tidak hanya mengatur ketentuan pidana formil namun juga mengatur ketentuan pidana materil terhadap anak yang terlibat dalam masalah hukum, khususnya dalam hukum pidana.

Dengan demikian apabila kita kaitkan dengan kasus dalam penelitian ini yitu Putusan Pengadilan Negeri Padangsidimpuan Nomor; 05/Pid.Sus.A/2012/PN.Psp dan juga dari segi Undang-undang Nomor 11 tahun 2012 entang Pengadilan Anak bahwasanya anak tersebut sudah dapat dijatuhi dengan hukuman sementara dari Undang-undang tersebut di atas batasan umurnya hanya dibawah dari pada 17 (tujuh belas) tahun, maka anak tersebut akan dikembalikan kepada orangtuanya atau dimasukkan ke dalam Lembaga Sosial Selanjutnya sebagaimana yang dikemukakan oleh Hakim Pengadilan Negeri Padangsidimpuan yang mengatakan bahwasanya anak-anak yang melakukan penyalahgunaan narkotika apabila kita kaitkan dengan Undang-undang Nomor 11 tahun 2012 tersebut memang benar dan jelas dimana seorang anak sebagai pelaku tindak pidana penyakahgunaan narkotika yang berada dibawah umur yang belum mengetahui apa penyebabnya terhadap anak tersebut yang hukumannya tidak diberikan hukuman penjara akan tetapi dikembalikan kepada orangtuanya atau dimasukkan kedalam Lembaga Sosial karena anak tersebut masih perlu pendidikan dan pengawasan dari orangtuanya agar nantinya apabila sesudah anak tersebut dewasa tidak akan melakukan tindak pidana penyalahgunaan narkotika tersebut. 
Berdasarkan penjelasan Hakim sebagaimaan tersebut di atas apabila dikaitkan dari Putusan Pengadilan Negeri Padangsidimpuan Nomor: 05/Pid.Sus.A/2012/PN.Psp dimana anak yang melakukan tindak pidana penyalahgunaan narkotika tersebut masih dapat digolongkan anak dibawah umur akan tetapi apabila juga dilihat dari segi Undang-undang Nomor 11 tahun 2012 tentang Pengadilan Anak tidak dapat lagi dokategorikan sebagai anak dibawah umur karena sudah tidak sesuai lagi dengan Undang-undang tersebut.

Sementara sebagaimana pendapat dari Hakim Pengadilan Negeri Padangsidimpuan mengatakan penjatuhan hukuman terhadap anak dibawah umur sesuai dengan Putusan Pengadilan Negeri Padangsidimpuan Nomor: 05/Pid.Sus.A/2012/PN.Psp pada dasarnya apabila kita lihat dari segi Undang-undang yang lain anak tersebut masih dapat digolongkan sebagai anak dibawa umur apabila tidak dikaitkan dengan Undang-undang Nomor 11 tahun 2012 tentang Pengadilan Anak, maka dengan itu terhadap putusan tersebut di atas seharusnya anak tersebut dapat dimasukkan ke dalam penjara karena dipertimbangkan dari Undangundang yang lain

\section{Pemidanaan Terhadap Anak Yang Melakukan Tindak Pidana Penyalahgunaan Narkotika}

Perbuatan memanfaatkan anak di bawah umur untuk melakukan kegiatan narkotika merupakan tindak pidana yang diatur dalam daalam Undang-undang Nomor 35 tahun 2009 tentang narkotika. Sebagaimana terhadap kasus narkotika atas nama Adek Saputra Alias Putra tempat lahir Batang Angkola, Umur/tanggal lahir 17 tahun/10 Oktober 1994, jenis kelamin laki-laki, kebangsaan Indonesia, tempat tinggal Jalan Mandailing Muara Tais Lingkungan VII, Kecamatan Batang Angkola, agama Islam, yang telah melanggar Pasal 111 ayat (1) Undang-undang Nomor 35 tahun 2009 tentang Narkotika Jo Undang-unang Nomor 3 tahun 1997 tentang Pengadilan Anak sesuai dengan Putusan Pengadilan Negeri Padangsidimpuan Nomor, 05/Pid.Sus.A/2012/PN.Psp dimana dijtuhi dengan hukuman 10 (sepuluh) bulan penjara.

Berdasarkan putusan Pengadilan Negeri padangsidimpuan tersebut di atas sebagaimana yang dikemukakan oleh Hakim Pengadilan Negeri Padangsidimpuan yang mengatakan bahwa apabila putusan Pengadilan Negeri Padangsidimpuan itu suah jelas sebagaimana yang terdapat di dalam Undang-undang Nomor 35 tahun 2009 tentang narkotika yang mana mengatakan setiap orang yang melawan hukum maupu yang menyalahgunakan narkotika 
sudah dapat dihukum sesuai dengan ketentuan Undang-undang tersebut. Selanjutnya apabila kita lihat dari Pasal yang dilanggar oleh terdakwa atas nama Rangga Mandala Putra Dalimunthe yaitu Pasal 111 ayat (1) Undang-undang Nomor 35 tahun 2009 tentang Narkotika di atas selanjutnya dikemukakan oleh Hakim Pengadilan Negeri Padangsidimpuan mengatakan hanya dikenakan kepada orang yang telah dewasa akan tetapi jika dilihat pula dari segi Undang-undang Nomor 11 tahun 2012 tentang Pengadilan Anak, maka Pasal yang dijatuhkan terhadap anak yang menyalahgunakan narkotika seperti yang terdapat dalam putusan tersebut di atas Hakim disini seharusnya memberikan hukuman terhadap anak tersebut dengan hukuman dikembalikan kepada pihak orangtuanya untuk mendidik anaknya supaya jangan lagi melakukan kejahatan tersebut ataupun dimasukkan kedalam Lembaga Sosial untuk diberikan pendidikan yang sesuai dengan umur anak tersebut.

Dari kasus di atas dapat dilihat bahwa Hakim tidak memutus lepas dari segala tuntutan hukum terdakwa atas nama Adek Saputra Alias Putra tersebut. Hakim menilai bahwa perbuatan terdakwa tersebut sudah dapat dikatakan suatu perbuatan yang akan merusak dirinya sendiri dan keluarganya karena sudah melakukan pelanggaran terhadap Undangundang Nomor 35 tahun 2009 dan Undang-undang Nomor 35 tahun 2014 tentang perlindungan anak.

Selain itu, dalam penjatuhan pidana, jikalau terdakwa tidak dilakukan penahanan, dapat diperintahkan oleh Hakim supaya terdakwa tersebut ditahan, apabila tindak pidana yang diancam dengan pidana penjara 5 tahun atau lebih, atau apabila tindak pidana itu termasuk yang diatur dalam ketentuan Pasal 21 ayat (4) huruf b KUHAP dan terdapat cukup alasan untuk itu. Dalam hal terdakwa dilakukan suatu penahanan, Pengadilan dapat menetapkan terdakwa tersebut tetap berada dalam tahanan atau membebaskannya, apabila terdapat cukup alasan untuk itu.

Sedangkan lamanya pidana, pembentuk Undang-undang memberi kebebasan kepada Hakim untuk menentukan antara pidana minimum sampai maksimum terhadap pasal yang terbukti dalam persidangan walaupun pembentuk Undang-undang memberi kebebasan menentukan batas maksimum dan minimum lama pidana yang harus dijalani terdakwa, bukan berarti hakim bisa seenaknya menjatuhkan pidana tanpa dasar pertimbangan yang lengkap

\section{Pemeriksaan Sidang Perkara Tindak Pidana Narkotika Terhadap Anak Di Pengadilan Negeri Padangsidimpuan}


Dalam proses di sidang Pengadilan Negeri Padangsidimpuan masalah tindak pidana narkotika terhadap anak dibawah umur juga merupakan suatu proses utama dibandingkan tindak pidana lainnya karena selain Wilayah Hukum Pengadilan Negeri Padangsidimpuan sudah kita ketahui rawan penyalahgunaan narkotika. Penjelasan di atas sebagaimana dijelaskan oleh Hakim Pengadilan Negeri Padangsidimpuan bahwa khusus tindak pidana narkotika tetap menjadi suatu perkara yang setiap saat di dahulukan persidangannya, karena masalah perkara narkotika ini sangat penting segera dituntaskan adalah dengan melihat dampak yang timbul jadi dengan masuknya suatu perkara narkotika di Pengadilan Negeri Padangsidimpuan jangan sampai ada anggapan suatu perkara yang dipermudah.

Lebih lanjut dijelaskan oleh Hakim Pengadilan Negeri Padangsidimpuan pada Pengadilan Negeri Padangsidimpuan tersebut di atas adalah mulai dari masuknya proses perkara tindak pidana narkotika ke Pengadilan masalah ini akan diregister secepatnya untuk kemudian diajukan kepada Ketua Pengadilan untuk menetapkan Hakim Majelis. Jika Ketua Pengadilan Negeri menyatakan cukup diperiksa dengan penunjukan Hakim saja apabila kasus narkotika tersebut pelakunya adalah anak dibawah umur maka perkara narkotika akan di proses sesuai dengan ketentuan hukum yang berlaku, karena masalah penentuan Hakim untuk mengadili perkara narkotika jika ditinjau dari ketentuan peraturan Perundang-undangan yang berlaku tidak ada salah satu pasal yang mengaturnya maka oleh sebab itu tidak jarang masalah penentuan Hakim ini sering menjadi kendala atau perdebatan sidang karena pelaku tindak pidana narkotika itu adalah seorang anak dibawah umur yang berhak mamariksa dan mengadilinya adalah dengan memakai Hakim tunggal. Apabila kita ketahui bahwa yang berwenang untuk menentukan Hakim adalah Ketua Pengadilan sedangkan apabila Ketua Pengadilan berhalangan yang berhak adalah Wakil Ketua Pengadilan maka tidak akan terjadi perdebatan seperti ditegasakan Hakim tersebut di atas bahwa penentuan Hakim yang akan mengadili kasus yang terjadi karena kalau kita lihat Undang-undang narkotika masalah ini tidak ada kita jumpai satu pasal pun, maka oleh sebab itu menurut Hakim tersebut tidak setiap perkara harus di adili dengan Hakim Majelis atau sebaliknya tidak pula setiap perkara narkotika harus diadili Hakim tunggal sebagaimana yang terdapat dalam Putusan Pengadilan Negeri Padangsidimpuan Nomor, 05/Pid.Sus.A/2012/PN.Psp tersebut dimana yang memeriksa dan mengadili adalah dengan memakai Hakim tunggal. Masalah tersebut di atas seperti dicontohkannya dalam tindak pidana narkotika yang dilakukan oleh seseorang atau 
beberapa orang anak dibawah umur dimana sekalipun dilakukan oleh anak dibawah umur maka harus tetap mengacu kepada pedoman proses peradilan anak yaitu tidak memakai toga, tertutup untuk umum dan diperiksa melalui Hakim tunggal. Akan tetapi jika sebaliknya dilakukan bersama-sama antara orang dewasa dengan anak dibawah umur maka perlakuan tersebut sudah dapat dikatakan sebagai yang besar sifatnya maka sejalan dengan itu juga harus diperiksa dengan penentuan Hakim Majelis.

Namun menurut Hakim Pengadilan Negeri Padangsidimpuan bahwa mengingat sifat dan skala perkara narkotika bukan hanya melindungi kepentingan Nasional melainkan sudah Internasional maka setiap pemeriksaan tindak pidana narkotika harus diperiksa dengan penentuan Hakim Mejelis adapun alasannya tidak lain karena dengan pemeriksaan sidang Pengadilan inipun harus diharapkan akan dapat difungsikan sebagai alat untuk pencegahan yang sekalipun sebagai alat penentu hukuman. Lebih lanjut dijelaskan oleh Hakim Pengadilan Negeri Padangsidimpuan mengatakan bahwa persoalan penentuan Hakim untuk menangani tindak pidana apapun termasuk tindak pidana narkotika adalah wewenang dari Ketua Pengadilan Negeri maka oleh sebab itulah dapat saya jelaskan bahwa penentuan Hakim Majelis atau Hakim tunggal yang akan menangani perkara-perkara narkotika ini. Dengan memperhatikan beberapa uraian tersebut di atas kiranya masalah penentuan Hakim yang akan menyidangkan suatu perkara narkotika di Pengadilan Negeri Padangsidimpuan ini tetap mengacu kepada ketentuan hukum acara hanya saja kewenangan yang diberikan Undang-undang untuk menentukan Hakim ini masih diperlukan atas kebijakan dari pada Ketua Pengadilan untuk selalu menetapkan atau menunjuk Hakim untuk menangani setiap kasus yang akan disidangkan di Pengadilan.

Dengan pertimbangan perbuatan terdakwa hanya menguasai 1 (satu) bungkus kecil diduga keras berisi Narkotika Golongan I jenis ganja Pengadilan Negeri Padangsidimpuan dalam perkara Nomor, 05/Pid.Sus.A/2012/PN.Psp telah menetapkan untuk memeriksa dan mengadili secara Hakim tunggal demikian juga dalam salah satu pertimbangan Hakim dalam putusannya mengatakan bahwa terdakwa adalah masih di bawah umur dan telah terbukti secara sah dan meyakinkan bersalah melakukan tindak pidana tanpa hak dan melawan hukum mempergunakan Narkotika Golongan I bagi diri sendiri dan juga terdakwa secara jujur telah mengakui perbuatannya serta terdakwa masih muda sehingga masih dapat diperbaiki perbuatannya sedangkan orang tua terdakwa berjanji akan membina terdakwa juga terdakwa 
telah menyesali perbuatannya. Dengan alasan pertimbangan di atas itulah pemeriksaan dilakukan dengan Hakim tunggal, seperti yang terdapat dalam putusan Pengadilan Negeri Padangsidimpuan Nomor. 05/Pid.Sus.A/2012/PN.Psp, dimana Hakim telah menjatuhkan hukuman terhadap terdakwa selama 10 (sepuluh) bulan penjara dan terdakwapun mendapat pengurangan hukum seluruhnya dari pidana yang dijatuhkan oleh Hakim Pengadilan Negeri Padangsidimpuan. Sesuai dengan penjelasn tersebut di atas sudah jelas bahwa penentuan Hakim tunggal dalam pemeriksaan perkara narkotika (ganja) bukan hanya dilihat dari berat ringannya perkara akan tetapi akibat yang ditimbulkan perlu di telusuri lebih jauh karena terdakwa masih di bawah umur

\section{KESIMPULAN DAN SARAN}

\section{Kesimpulan}

a. Bahwa pertanggungjawaban hokum terhadap anak dibawah umur sebagai pelaku tindak pidana narkotika di Wilayah Hukum Pengadilan Negeri Padangsidimpuan sebagaimana yang terdapat dalam Pasal 24 Undang-undang Nomor 3 tahun 1997 tentang Pengadilan Anak bahwa tindakan yang dapat dijatuhkan kepada anak nakal ialah mengembalikan kepada orang tua, wali atau orang tua asuh, dengan menyerahkan kepada Negara untuk mengikuti pendidikan, pembinaan dan latihan kerja atau menyerahkan kepada Departemen Sosial atau organisasi Sosial Kemasyarakatan yang bergerak dibidang pendidikan, pembinaan dan latihan kerja

b. Bahwa proses pemidanaan terhadap anak dibawah umur yang melakukan tindak pidana penyalahgunaan narkotika dalam praktek di Pengadilan Negeri Padangsidimpuan pada dasarnya belum sesuai dengan Undang-undang 3 tahun 1997 karena seperti kasus dalam penelitian ini dimana terdakwa telah dijatuhi hukuman selama 10 (sepuluh) bulan penjara yang berarti Hakim hanya berpedoman kepada Undang-undang Nomor 35 tahun 2009 tentang Narkotika sebagaimana yang terdapat di dalam Pasal 111

\section{Saran}


a. Bahwa di dalam pemidanaan terhadap anak dibawah umur yang melakukan tindak pidana penyalahgunaan narkotika dalam praktek di Pengadilan Negeri Padangsidimpuan masih berpedomana kepada hukum positif saja dan tidak mempertimbangkan Undang-undang Nomor 3 tahun 1997 tentang Pengadilan Anak seharusnya Hakim harus melihat motip yang dilakukan anak dibawah umur tersebut dan juga dikaitkan dengan Undang-undang tersebut di atas yang mengatakan bahwa apabila seorang anak yang melakukan tindak pidana penyalahgunaan narkotika tidak perlu dijatuhi dengan hukuman penjara akan tetapi dikembalikan kepada orangtua atau dimasukkan ke Lembaga Sosial untuk diberikan pendidikan

b. Bahwa untuk mengatsi faktor penghambat dalam membarantas tindak pidana penyalahgunaan narkotika terhadap anak dibawah umur adalah dengan melakukan pendekatan terahdap anak tersebut ataupun mengadakan penyuluhan hukum dan sosialisasi Undang-undang Nomor 35 tahun 2009 tentang narkotika terhadap masyarakat agar supaya masyarakat sendiri mengetahui bagaimana bahayanya narkotika itu terhadap diri sendiri dan juga terahdap keluarga

\section{DAFTAR PUSTAKA}

Adami Chazawi, 2002, Pelajaran Hukum Pidana Bagian Pertama, Raja Grafindo, Jakarta Andi Hamzah dan A. Sumangalepu, 1983, Pidana Mati di Indonesia, Ghalia Indonesia,

JakarAbdussalam, 2007, Hukum Perlindungan Anak, Restu Agung, Jakarta

A.Syamsudin Meliala dan E.Sumaryono, 1985, Kejahatan Anak Suatu Tinjauan dari Psikologis dan Hukum, Liberty, Yogyakarta

B. Simanjuntak, 1981, Pengantar Kriminologi Dan Patologi Sosial, Tarsito, Bandung

Consevela G Sevilla 1993, Metode Deskriptif, UI, Press, Jakarta

Dirjen Dikti Depdikbud, 1993, Bahan Penataran dan Referensi Penataran, Jakarta

Gempur Sentosa 2005, Metode Penelitian, Prestasi Pustaka Publisher, Jakarta

H. Hadari Nawawi,1990, Metode Penelitian, Raja Grafindo, Jakarta

Kartini Kartono, 1992, Pathologi Sosial (2), Kenakalan Remaja, Rajawali Pers, Jakarta Leden Marpaung, 2005, Asas-Teori-Praktek Hukum Pidana,Sinar Grafika, Jakarta 
Volume 1 No (1) 2019

Mardjono Reksodiputro, 1994, Hak Asasi Manusia Dalam Sistim Peradilan Pidana, Universitas Indonesia, Jakarta

Mariman Prodjohamidjoyo,2001, Penerapan Pembuktian terbalik dalam Delik Korupsi (UU N0. 31 tahun 1999), Bandar Maju, Bandung

Pramuka Saka Bhayangkara, 1997, Wahai Kaum Muda Jangan Berpacu Dengan Ekstasi.

Penanggulangan Bahaya Narkotika dan Psikotropika, Bina Darma Pemuda Printing, Jakarta

Purnianti, Mamik Sri Supatmi, dan Ni Made Martini Tinduk, 2003, Analisa Situasi Sistem Peradilan Pidana Anak, UNICEF, Indonesia

Romli Atmasasmita, 1996, Sistem Peradilan Pidana : Perspektif Eksistensialisme dan Abolisionisme, Putra A. Bardin, Bandung

Sumadi Suryabrata, 1983, Metode Penelitian, Rajawali, Jakarta

Sudaryono dan Natangsa Surbakti, 2005, Buku Pegangan Kuliah Hukum Pidana, UMS Press, Jakarta

Sudarto, 1982, Hukum Dan Hukum Pidana, Alumni, Bandung

Sudarsono, 1991, Kenakalan Remaja, Rineka Cipta, Jakarta

Sudjana, 2008, Metodologi Penelitian, Sinar Grafindo, Grafindo, Jakarta

Sudarto,1997, Metodologi Filsafat, Raja Grafindo Persada, Jakarta

Departemen Kehakiman Republik Indonesia, Undang-undangNomor 35 Tahun 2009 Tentang Narkotika

Departemen Kehakiman, Republik Indonesia, Rancangan Undang-undang Kitab Undangundang Hukum Pidana, Jakarta, 2004

Departemen Kehakiman Republik Indonesia, Undang-undang Nomor 23 Tahun 2002 tentang Peradilan Anak, Citra Umbara, Bandung

Departemen Kehakiman Republik Indonesia, Undang-undang Nomor 39 Tahun 1999 Tentang Undang-Undang Hak Asasi Manusia. Rajwali Press, Jakarta

Departemen Kehakiman Republik Indonesia, Undang-undang Nomor 3 Tahun 1997 tentang Pengadilan Anak, Jakarta 